\title{
Analisa Teknis dan Biaya Penggunaan Bahan Bakar Cangkang Kelapa Sawit dan Batu Bara pada Boiler DZL4 di PT. Lautan Luas Tbk.
}

\author{
Laili Budi Hartanto ${ }^{1, a)}$, Maradu Sibarani ${ }^{2, b)}$, J. Victor Tuapetel ${ }^{2, c)}$ \\ ${ }^{1}$ PT Lautan Luas Tbk., \\ Gedung Graha Indramas, Jl. K.S. Tubun Raya No.77, Slipi, Jakarta Barat, Indonesia, 11410 \\ ${ }^{2,3}$ Program Studi Teknik Mesin ITI, \\ Jl. Raya Puspiptek Serpong, Tangerang Selatan-Banten, Indonesia, 15320 \\ a)hartanto.lb@gmail.com, b) sibaranimaradu@yahoo.com, ${ }^{\mathrm{c})}$ jvictor.tuapetel@iti.ac.id
}

\begin{abstract}
Abstrak
Boiler DZL4 dengan tipe solid fuel dioperasikan di PT. Lautan Luas Tbk untuk proses reaksi kimia. Penelitian ini bertujuan untuk menganalisa jumlah kebutuhan serta biaya bahan bakar batu bara jenis bituminus dan cangkang sawit. Variabel bebas adalah kapasitas boiler 2,5 ton/jam, 3 ton/jam, 4 ton/jam. Variabel konstan adalah tekanan steam 1,25 $\mathrm{MPa}$, temperatur steam $194^{\circ} \mathrm{C}$, temperatur air umpan $75^{\circ} \mathrm{C}$ pada tekanan $0,15 \mathrm{MPa}$, efisiensi boiler $78,8 \%$. Metode penelitian adalah dengan menghitung kebutuhan kalor boiler, kebutuhan bahan bakar, jumlah biaya untuk setiap jenis bahan bakar dilanjutkan dengan analisa. Hasil perhitungan kalor boiler kapasitas 2,5 ton/jam, 3 ton/jam, 4 ton/jam berturut-turut adalah 1.482.476 kkal/jam, $1.778 .972 \mathrm{kkal} / \mathrm{jam}, 2.371 .962 \mathrm{kkal} / \mathrm{jam}$. Berdasarkan kebutuhan kalor boiler pada tiap kapasitas, maka kebutuhan bahan bakar batu bara dan cangkang sawit per jam berturut-turut sebesar $304 \mathrm{~kg}$, $364 \mathrm{~kg}, 483 \mathrm{~kg}$ dan $430 \mathrm{~kg}, 511 \mathrm{~kg}, 681 \mathrm{~kg}$. Kemudian berdasarkan jumlah konsumsi bahan bakar pada tiap kapasitas boiler, maka biaya untuk batu bara dan cangkang sawit per jam berturut-turut adalah Rp350.000, Rp419.000, Rp555.500, dan Rp365.500, Rp435.500, Rp579.000. Berdasarkan data hasil perhitungan tersebut, berkaitan dengan penggunaan jumlah bahan bakar dan biaya yang dibutuhkan, maka bahan bakar batu bara lebih efisien digunakan untuk pengoperasian Boiler DZL4 pada tiap kapasitas.
\end{abstract}

Kata kunci: boiler, solid fuel, cangkang sawit, batu bara, biaya

\begin{abstract}
The Boiler DZL4 with solid fuel type are operated in PT. Lautan Luas Tbk for chemical reaction processes. The purpose of this research is to analize the amount of use and costs between palm kernel shell and bituminous type of coal. The independent variables are boiler capacity of 2,5 tons/hour, 3 tons/hour and 4 tons/hour. The constant variable is steam pressure $1,25 \mathrm{MPa}$, steam temperature $194^{\circ} \mathrm{C}$, feed water temperature $75^{\circ} \mathrm{C}$ at 0,15 MPa pressure and boiler efficiency $78,8 \%$. The research method is to calculate the boiler heat requirements, amount of fuel needs, the costs for each type of fuel then continue the analysis. The results of heating boiler calculations for capacity of 2,5 tons/hour, 3 tons/hour and 4 tons/hour respectively are $1.482 .476 \mathrm{kcal} / \mathrm{hour}, 1.778 .972 \mathrm{kcal} / \mathrm{hour}, 2.371 .962 \mathrm{kcal} / \mathrm{hour}$. Based on boiler heat requirements at each capacity, the fuel consumption of coal and palm kernel shells per hour respectively are $304 \mathrm{~kg}, 364 \mathrm{~kg}, 483 \mathrm{~kg}$, and $430 \mathrm{~kg}, 511 \mathrm{~kg}, 681 \mathrm{~kg}$. Based on the amount of fuel consumption in each boiler capacity, the cost for coal and palm kernel shells per hour respectively are Rp350.000, Rp419.000, Rp555.500, and Rp365.500, Rp435.500, Rp579.000. Based on the calculation data, related to the use of the amount of fuel and the cost required, the coal fuel is more efficiently used for the operation of DZL4 Boilers at each capacity.
\end{abstract}

Keywords: boiler, solid fuel, palm kernel shell, coal, cost

\section{PENDAHULUAN}

\section{A. Latar Belakang}

Salah satu utilitas utama yang memiliki peranan penting dalam industri kimia adalah mesin penghasil uap panas (boiler). Uap panas bertekanan (steam) digunakan untuk proses reaksi kimia mesin reaktor yang ada di PT. Lautan Luas Tbk pada tiga plant area yaitu PACS, PACV, dan Hinco Alpha (HA) Plant. Boiler DZL4 memiliki kapasitas 4 ton/jam dan dapat menghasilkan tekanan uap sebesar $1,25 \mathrm{MPa}$ pada temperatur $194^{\circ} \mathrm{C}$.
Berdasarkan tipe boiler yaitu solid fuel, maka Boiler DZL4 tersebut dapat menggunakan bahan bakar cangkang sawit dan batu bara. Selama ini pengoperasian boiler tersebut selalu menggunakan cangkang sawit, akan tetapi penggunaan cangkang sawit tersebut memiliki kelemahan yaitu moisture content yang cukup tinggi dan nilai kalor pembakaran yang rendah terutama pada saat musim penghujan, sehingga waktu pembakaran yang dibutuhkan dalam boiler menjadi lebih lama.

Pada penelitian kali ini dilakukan analisa perbandingan secara teknis dan ekonomis terhadap penggunaan bahan 
bakar cangkang sawit maupun batu bara jenis bituminus. Metode yang dilakukan adalah dengan melakukan perhitungan konsumsi masing-masing bahan bakar berdasarkan jumlah kalor yang dibutuhkan boiler serta tekanan dan temperatur yang diperlukan untuk proses rekasi kimia pada mesin reaktor. Perhitungan dilakukan dengan variasi kapasitas beban boiler yang berbeda-beda berdasarkan kebutuhan masing-masing plant area.

Untuk PACS Plant, PACV Plant, dan HA Plant masing-masing membutuhkan laju aliran steam berturutturut sebesar 1,25 ton/jam, 1 ton/jam, dan 1,25 ton/jam. Berdasarkan kebutuhan tersebut maka variasi kapasitas boiler yang dihitung adalah 2,5 ton/jam, 3 ton/jam dan 4 ton/jam. Dari hasil perhitungan dan analisa yang dilakukan, diharapkan dapat dijadikan sebagai bahan evaluasi konsumsi bahan bakar Boiler DZL4 tersebut sehingga tepat dan efisien sesuai kebutuhan dan pertimbangan manajemen perusahaan.

\section{B. State Of The Art}

Analisis teknis dan ekonomis terhadap penggunaan bahan bakar boiler telah dilakukan pada PLTU PT. Suka Jaya Makmur. Dari penelitian terhadap boiler dengan kapasitas 32 ton/jam, tekanan uap 3,2 $\mathrm{MPa}$ pada temperatur $420{ }^{\circ} \mathrm{C}$ dan temperatur air umpan $90{ }^{\circ} \mathrm{C}$ membutuhkan kalor sebesar $24679424 \mathrm{kcal} / \mathrm{jam}$. Berdasarkan data teknis boiler, dengan efisiensi 90\% maka jumlah bahan bakar yang diperlukan untuk kayu, batu bara, cangkang sawit masing-masing adalah 6,2 ton/jam, 5,9 ton/jam, dan 5,1 ton/jam. Kemudian biaya yang harus dikeluarkan untuk masing-masing bahan bakar tersebut adalah Rp. 1,2 juta/jam, Rp. 3,2 juta/jam, dan Rp. 1,2 juta/jam [1]

Analisa pemakaian bahan bakar dengan pengujian nilai kalor bahan bakar dilakukan terhadap ketel uap kapasitas 60 ton/jam. Dari hasil penelitian diperoleh kesimpulan bahwa nilai kalor bahan bakar mempengaruhi jumlah kebutuhan penggunaan bahan bakar boiler. Semakin besar nilai LHV (low heating value) maka semakin sedikit jumlah bahan bakar yang digunakan, dan semakin tinggi efisiensi boiler yang dihasilkan, hal tersebut juga berlaku sebaliknya [2].

Penelitian dilakukan pada boiler Ebara HKL 1800KA dengan kapasitas $3385 \mathrm{~kg} / \mathrm{jam}$, tekanan uap 7 bar pada temperature $145^{\circ} \mathrm{C}$. Dengan efisiensi boiler sebesar 60,2 $\%$ diperlukan jumlah bahan bakar untuk solar sebesar $0,265 \mathrm{~m}^{3} / \mathrm{jam}$ dan $21 \mathrm{~m}^{3} / \mathrm{jam}$ untuk LNG. Biaya yang diperlukan untuk solar sebesar Rp. 1.319.797,- /jam dan Rp. 27.300,- /jam untuk LNG [3].

Penelitian dilakukan terhadap boiler pada PLTU dengan variasi bahan bakar solar (HSD), gas (LNG), dan batu bara. Untuk kebutuhan kalor boiler sebesar $139,94 \times 10^{6} \mathrm{kkal} / \mathrm{jam}$ laju aliran massa bahan bakar HSD, LNG, batu bara yang dibutuhkan masing-masing adalah $13446,95 \mathrm{~kg} / \mathrm{jam}, 11567,94 \mathrm{~kg} / \mathrm{jam}, 29032,52 \mathrm{~kg} / \mathrm{jam}$. Sedangkan perkiraan biaya pertahun yang dibutuhkan untuk masing-masing bahan bakar adalah Rp. 890,73 milyar/tahun untuk HSD, Rp. 154,63 milyar/tahun untuk LNG, dan Rp. 87,61 milyar/tahun apabila menggunakan batu bara [4].

\section{LANDASAN TEORI}

\section{A. Defnisi Boiler}

Boiler atau ketel uap adalah bejana bertekanan (pressure vessel) dimana panas pembakaran dialirkan ke air sampai terbentuk uap panas atau steam. Ketel uap juga termasuk mesin konversi energi yang mengubah energi kimia dari bahan bakar menjadi energi uap atau energi panas. Sistem boiler terdiri atas sistem air umpan, sistem uap panas (steam) dan sistem bahan bakar. Sistem air umpan menyediakan air untuk boiler secara otomatis sesuai dengan kebutuhan tekanan steam. Sistem steam mengumpulkan dan mengontrol produksi steam dalam boiler. Steam dialirkan melalui sistem perpipaan ke titik lokasi penggunaan. Sistem bahan bakar adalah semua peralatan yang digunakan untuk menyediakan bahan bakar dan melakukan proses pembakaran untuk menghasilkan panas yang dibutuhkan. Peralatan yang diperlukan pada ruang pembakaran (furnace) tergantung pada jenis bahan bakar yang digunakan pada sistem boiler atau tipe dari boiler tersebut, apakah liquid, gas, solid fuel atau kombinasi [5].

Bagian utama boiler secara umum terdiri dari boiler drum, furnace, burner, economizer, superheater, chimney (cerobong). Selain itu juga ditunjang dengan sistem pengumpan air dan sistem bahan bakar. Gambar 1 berikut ini menyajikan skematis instalasi kelengkapan standar minimal yang terdapat pada sistem boiler.

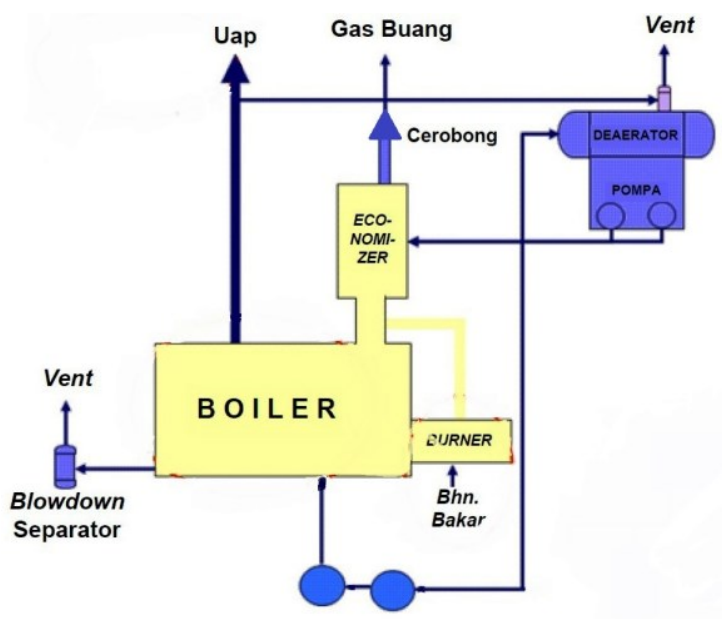

Gambar 1. Skematis Instalasi Kelengkapan Standar Boiler

\section{B. Klasifikasi Boiler}

Berdasarkan aliran fluida yang terdapat didalam boiler, secara garis besar boiler dibedakan menjadi 2 tipe utama, yaitu tipe fire tube boiler (boiler pipa api) dan tipe water tube boiler (boiler pipa air).

\section{Boiler Pipa Api (Fire Tube Boiler)}

Pada Gambar 2 Fire Tube Boiler, gas panas hasil pembakaran boiler melewati pipa-pipa (fire tube) untuk memanaskan air umpan (feed water) yang terdapat didalam shell (bejana boiler) untuk diubah menjadi uap panas bertekanan (steam). Ketel uap pipa api pada umumnya digunakan untuk kebutuhan kapasitas steam yang relatif kecil dengan tekanan dan temperatur steam rendah dan sedang. 


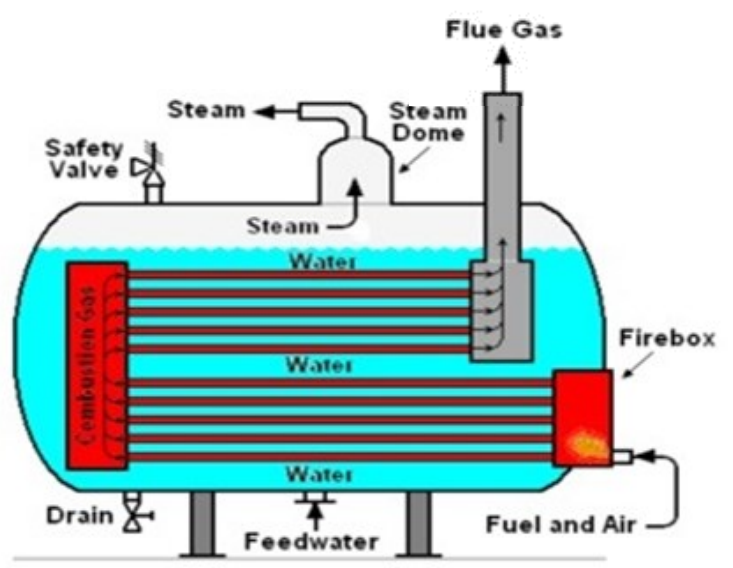

Gambar 2. Fire Tube Boiler

\section{Boiler Pipa Air (Water Tube Boiler)}

Pada Gambar 3 Water Tube Boiler, air umpan boiler mengalir melalui pipa-pipa masuk kedalam drum. Air yang tersirkulasi dipanaskan oleh gas panas hasil pembakaran kemudian membentuk steam pada daerah uap dalam drum. Ketel ini dipilih jika kebutuhan laju alian steam dan tekanan steam sangat tinggi seperti pada ketel uap untuk pembangkit tenaga listrik

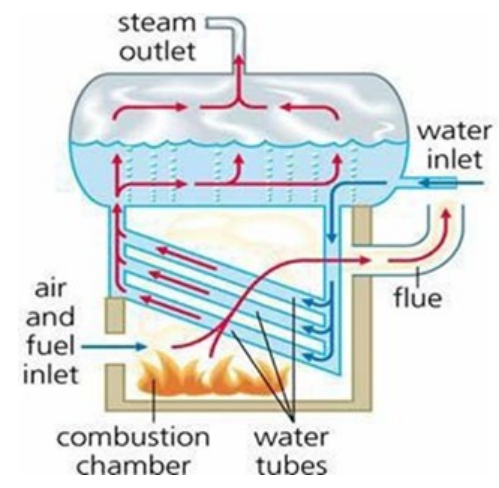

Gambar 3. Water Tube Boiler

\section{Proses Pembentukan Uap}

Penguapan adalah proses terjadinya perubahan fasa dari cairan menjadi uap. Apabila panas diberikan pada air, maka suhu air akan naik. Naiknya suhu air akan meningkatkan kecepatan gerak molekul air. Jika panas terus bertambah secara perlahan-lahan, maka kecepatan gerak air akan semakin meningkat pula, hingga sampai pada suatu titik dimana molekul-molekul air akan mampu melepaskan diri dari lingkungannya pada temperature $100^{\circ} \mathrm{C}$ dan tekanan 1 atmosphere, maka air secara berangsur-angsur akan berubah fasa menjadi uap dan hal inilah yang disebut sebagai penguapan. Temperatur air pada saat itu mencapai temperatur didih, meskupin panas masih saja ditambahkan besarnya, temperatur didih tidak akan berubah atau konstan, selama tekanan yang ada dipertahankan secara konstan. Berdasarkan siklus Rankine proses pembentukan uap pada boiler dapat dilihat pada Gambar 4 Diagram T-s berikut ini [6].

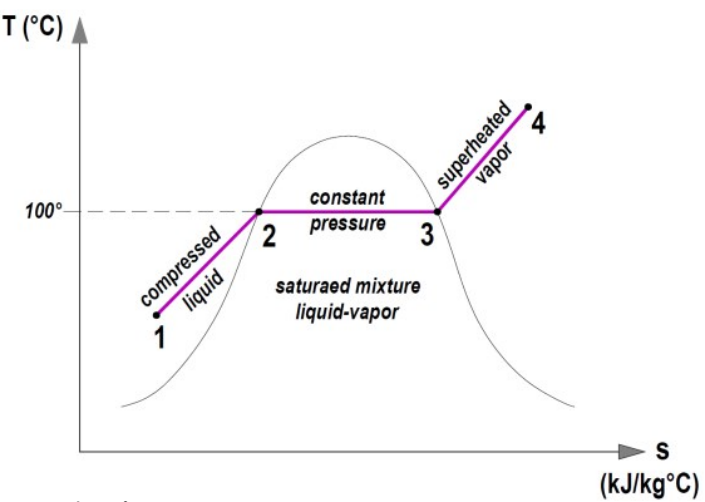

Gambar 4. Diagram T-s Penguapan

\section{Bahan Bakar}

Bahan bakar adalah segala bahan yang dapat dibakar, suatu materi apapun yang bisa diubah menjadi energi panas. Kebanyakan bahan bakar digunakan manusia melalui proses pembakaran (reaksi redoks) dimana bahan bakar tersebut akan melepaskan panas setelah direaksikan dengan oksigen. Proses pembakaran merupakan proses kimia antara bahan bakar, udara dan panas. Proses pembakaran yang terjadi di dalam ruang bakar ketel uap (furnace) bertujuan untuk mendapatkan kalor yang dapat merubah air menjadi uap [7].

\section{Cangkang Kelapa Sawit}

Cangkang kelapa sawit adalah limbah pengolahan minyak kelapa sawit yang cukup besar jumlahnya, yaitu mencapai $\pm 60 \%$ dari total komposisi biji kelapa sawit. Sebagai bahan bakar padat biomassa, cangkang kelapa sawit dapat diperbarui dan tingkat ketersediaannya tinggi atau mudah untuk didapatkan dibanding bahan bakar padat tipe fosil. Pada umumnya komposisi kimia cangkang kelapa sawit terdiri dari: oksigen $(34,06 \%)$, karbon (49,79\%), hidrogen (5,58\%), nitrogen $(0,72 \%)$, sulfur $(0,08 \%)$, air $(9,77 \%)$

\section{Batu Bara}

Batubara adalah mineral organik yang dapat terbakar, terbentuk dari sisa tumbuhan purba yang mengendap yang selanjutnya berubah bentuk menjadi padatan akibat proses fisika dan kimia yang berlangsung selama jutaan tahun. Jenis batu bara berdasarkan kualitas nilai kalornya, yaitu: antrasit, bituminus, lignit, gambus. Batu bara jenis bituminus memiliki komposisi kimia: oksigen $(11,88 \%)$, karbon $(58,96 \%)$, hidrogen $(4,16 \%)$, nitrogen $(1,02 \%)$, sulfur $(0,56 \%)$, air $(9,43 \%)$, bahan mineral $(13,99 \%)$.

\section{E. Nilai Kalor Bahan Bakar}

Nilai kalor merupakan energi kalor yang dilepaskan bahan bakar pada waktu terjadinya oksidasi unsur-unsur kimia yang ada pada bahan bakar tersebut. Data yang diperlukan untuk menghitung nilai kalor tersebut adalah persentase kandungan karbon $(\mathrm{C})$, hidrogen $\left(\mathrm{H}_{2}\right)$, oksigen $\left(\mathrm{O}_{2}\right)$, sulfur $(\mathrm{S})$, dan kadar air atau moisture content $(\mathrm{M})$ dari bahan bakar [7]. 
Nilai Kalor Pembakaran Tinggi

Dikenal dengan istilah High Heating Value (HHV) atau Gross Calorific Value (GCV) adalah nilai pembakaran dimana panas pengembunan air dari proses pembakaran ikut diperhitungkan sebagai panas dari proses pembakaran, dirumuskan dengan:

$\mathrm{HHV}=33950 \mathrm{C}+144200\left(\mathrm{H}_{2}-\mathrm{O}_{2} / 8\right)+9400 \mathrm{~S}(\mathrm{kj} / \mathrm{kg})$

\section{Nilai Kalor Pembakaran Rendah}

Dikenal dengan istilah Low Heating Value (LHV) atau Net Calorific Value (NCV) adalah nilai pembakaran dimana panas pengembunan uap air dari hasil pembakaran tidak ikut dihitung sebagai panas dari proses pembakaran, dirumuskan dengan:

$\mathrm{LHV}=\mathrm{HHV}-2411\left(\mathrm{M}+9 \mathrm{H}_{2}\right)(\mathrm{kj} / \mathrm{kg})$

\section{F. Parameter Kinerja Boiler}

Dalam analisa kinerja boiler ada beberapa parameter perhitungan, yaitu: jumlah kalor yang dibutuhkan boiler $\left(\mathrm{Q}_{\mathrm{b}}\right)$, jumlah bahan bakar yang dibutuhkan $\left(m_{f}\right)$, jumlah kalor yg dihasilkan $\left(\mathrm{Q}_{\text {in }}\right)$, efisiensi thermal boiler $\left(\eta_{\mathrm{b}}\right)[8]$.

Jumlah Kalor Yang Dibutuhkan Boiler

Dihitung menggunakan rumus berikut ini:

$$
Q_{b}=m_{s}\left(h_{s}-h_{w}\right)
$$

Dimana:

$\mathrm{Q}_{\mathrm{b}} \quad$ : Jumlah kalor yang dibutuhkan boiler $(\mathrm{kJ} / \mathrm{jam})$

$\mathrm{m}_{\mathrm{s}} \quad$ : Kapsitas boiler atau laju aliran steam $(\mathrm{kg} / \mathrm{jam})$

$\mathrm{h}_{\mathrm{s}} \quad$ : Entalpi uap panas lanjut $(\mathrm{kJ} / \mathrm{kg})$

$\mathrm{h}_{\mathrm{w}} \quad$ : Entalpi air umpan boiler $(\mathrm{kJ} / \mathrm{kg})$

Jumlah Bahan Bakar Yang Dibutuhkan Boiler

Dihitung menggunakan rumus berikut ini:

$m_{f}=\frac{Q b}{\eta \mathrm{b} \times L H V}$

$\mathrm{m}_{\mathrm{f}} \quad$ : Jumlah bahan bakar boiler $(\mathrm{kg} / \mathrm{jam})$

$\mathrm{Q}_{\mathrm{b}}$ : Jumlah kalor yang dibutuhkan boiler $(\mathrm{kJ} / \mathrm{jam})$

LHV: Low Heating Value bahan bakar $(\mathrm{kJ} / \mathrm{kg})$

$\eta_{\mathrm{b}} \quad$ : Efisiensi boiler

\section{Jumlah Kalor Hasil Pembakaran}

Dihitung menggunakan rumus berikut ini:

$$
Q_{i n}=m_{f} x L H V
$$

Dimana:

$Q_{\text {in }}:$ Jumlah kalor hasil pembakaran $(\mathrm{kJ} / \mathrm{jam})$

$\mathrm{m}_{\mathrm{f}}$ : Jumlah bahan bakar boiler $(\mathrm{kg} / \mathrm{jam})$

LHV: Low Heating Value bahan bakar $(\mathrm{kJ} / \mathrm{kg})$

\section{Efisiensi Thermal Boiler}

Dihitung menggunakan rumus berikut ini:

$$
\eta_{b}=\frac{Q b}{Q i n} \times 100 \%
$$

Dimana:

$$
\begin{aligned}
& \mathrm{Q}_{\text {in }}: \\
& \mathrm{Q}_{\mathrm{b}}: \text { Jumlah kalor hasil pembakaran }(\mathrm{kJ} / \mathrm{jam}) \\
& \text { Jumlah kalor yang dibutuhkan boiler }(\mathrm{kJ} / \mathrm{jam})
\end{aligned}
$$

\section{METODE PENELITIAN}

Tahapan penelitian yang dilakukan mengikuti diagram alir pada Gambar 5 berikut ini.

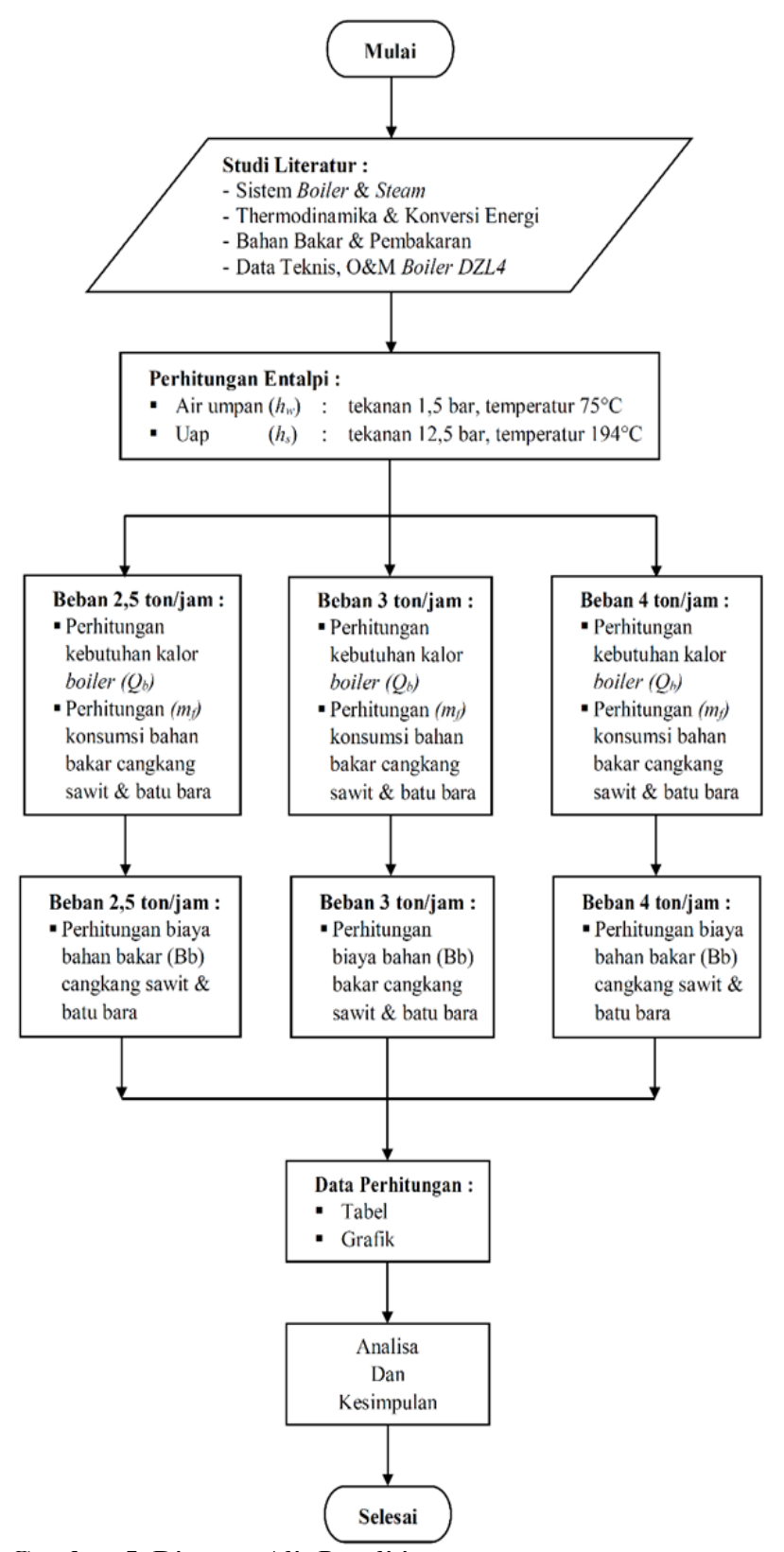

Gambar 5. Diagram Alir Penelitian

Kemudian untuk data teknis objek penelitian adalah sebagai berikut :

- Variasi kapasitas boiler : 2,5 ton/jam ( $\quad$ ( $\left.\boldsymbol{m}_{\boldsymbol{s} 1}\right)$

$$
3 \text { ton/jam } \quad\left(\boldsymbol{m}_{\boldsymbol{s} 2}\right)
$$$$
4 \text { ton/jam } \quad\left(m_{s 3}\right)
$$

- Tekanan kerja steam $\quad: \quad 1,25 \mathrm{MPa} \approx 12,5 \mathrm{bar}$

- Temperatur steam : $194^{\circ} \mathrm{C}$

- Tekanan air umpan $\quad: \quad 0,15 \mathrm{MPa} \approx 1,5$ bar

- Temperatur air umpan $\quad: \quad 75^{\circ} \mathrm{C}$

- Efisiensi boiler $\quad$ : $78,8 \%$

- LHV cangkang sawit : $\quad 4414 \mathrm{kkal} / \mathrm{kg}$

- LHV batu bara bituminus : $6198 \mathrm{kkal} / \mathrm{kg}$ 
- Entalpi air umpan

- Entalpi uap panas

: $\quad 314,12 \mathrm{~kJ} / \mathrm{kg}$

$2796,81 \mathrm{~kJ} / \mathrm{kg}$

$\left(\boldsymbol{h}_{w}\right)$

$\left(h_{s}\right)$

\section{HASIL DAN PEMBAHASAN}

\section{A. Kebutuhan Kalor Boiler}

Hasil perhitungan kebutuhan kalor boiler dapat dilihat pada diagram Gambar 6 berikut ini.

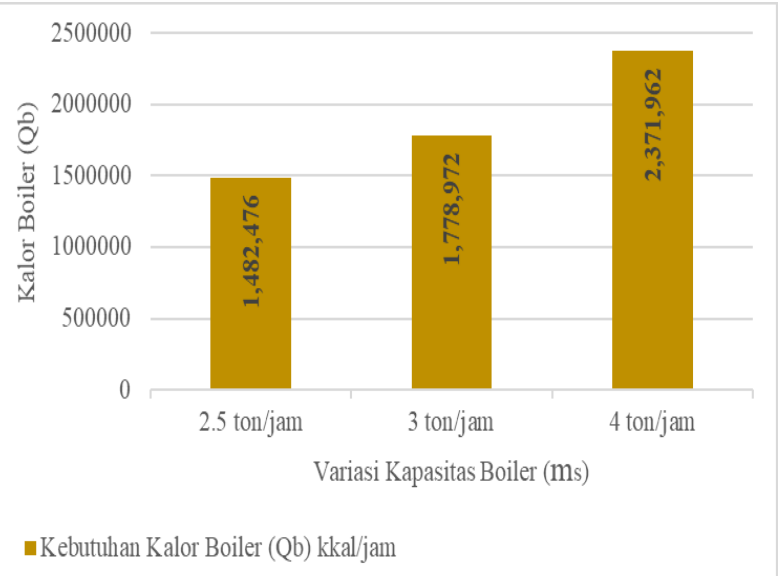

Gambar 6. Diagram Kebutuhan Kalor Boiler

Berdasarkan data tersebut, besar kapasitas boiler atau steam flow rate mempengaruhi jumlah kebutuhan kalor boiler. Pada kapasitas 2,5 ton/jam jumlah kalor yg dibutuhkan sebesar $1.482 .476 \mathrm{kkal} / \mathrm{jam}$. Kemudian pada kapasitas 3 ton/jam jumlah kalor yg dibutuhkan sebesar 1.778.972 kkal/jam dan tertinggi kebutuhan kalor boiler pada kapasitas 4 ton/jam yaitu sebesar 2.371.962 $\mathrm{kkal} / \mathrm{jam}$. Hal ini menunjukkan bahwa semakin besar kapsitas yang ingin dihasilkan, maka semakin tinggi pula kebutuhan kalor dari boiler.

\section{B. Kebutuhan Bahan Bakar Boiler}

Hasil perhitungan kebutuhan bahan bakar boiler dapat dilihat pada diagram Gambar 7 berikut ini.

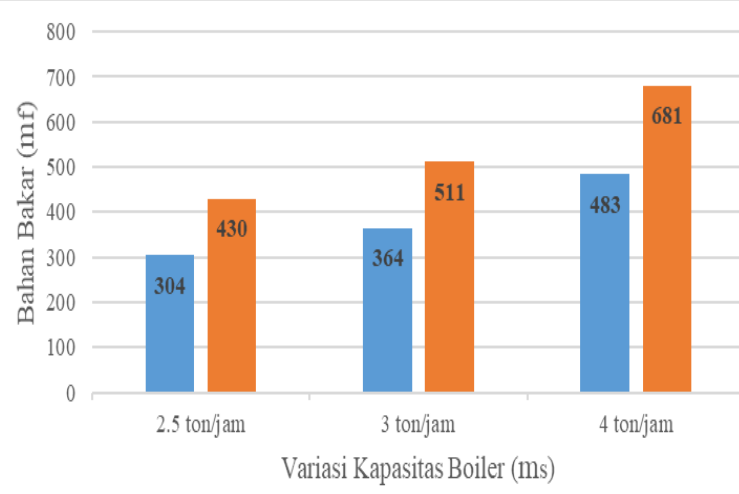

- Konsumsi Bahan Bakar (mf) Batı Bara (kg/jam)

-Konsumsi Bahan Bakar (mf) Cangkang Sawit (kg/jam)

Gambar 7. Diagram Kebutuhan Bahan Bakar Boiler

Besar kalor yang dibutuhkan boiler mempengaruhi jumlah penggunaan bahan bakar. Selain itu juga, jumlah kebutuhan bahan bakar juga tergantung pada nilai LHV
(Low Heating Value) dari bahan bakar yang digunakan. Untuk bahan bakar batu bara dengan nilai LHV lebih tinggi, jumlah kebutuhan bahan bakar setaip jam (kg/jam) lebih sedikit dibandingkan dengan bahan cangkang sawit dengan nilai LHV yang lebih rendah. Pada kapasitas 2,5 ton/jam, 3 ton/jam, dan 4 ton/jam berturut-turut jumlah bahan bakar batu bara yang dibutuhkan sebesar 304 $\mathrm{kg} / \mathrm{jam}, 364 \mathrm{~kg} / \mathrm{jam}$, dan $483 \mathrm{~kg} / \mathrm{jam}$. Kemudian untuk bahan bakar cangkang kelapa sawit secara berturut-turut pada kapasitas boiler 2,5 ton/jam, 3 ton/jam, dan 4 ton/jam jumlah bahan bakar yang dibutuhkan sebesar 430 $\mathrm{kg} / \mathrm{jam}, 511 \mathrm{~kg} / \mathrm{jam}$, dan $681 \mathrm{~kg} / \mathrm{jam}$.

\section{Biaya Bahan Bakar Boiler}

Hasil perhitungan biaya bahan bakar boiler dapat dilihat pada diagram Gambar 8 berikut ini.

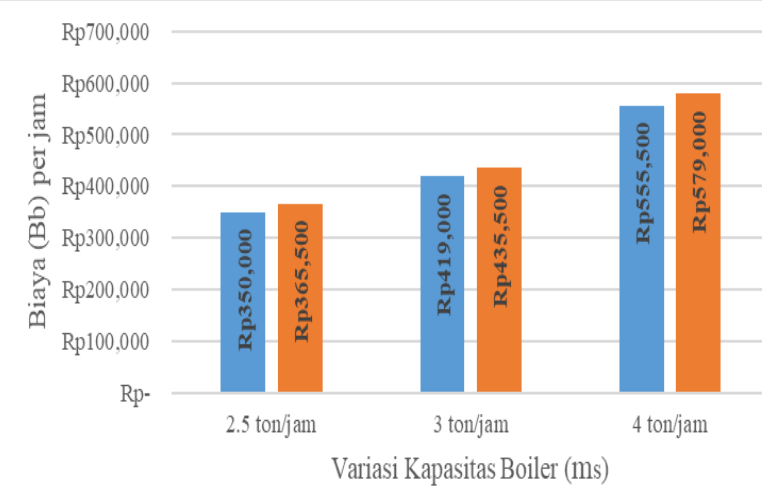

- Biaya Bahan Bakar (Bb) per jam Batu Bara

- Biaya Bahan Bakar (Bb) per jam Cangkang Sawit

Gambar 8. Diagram Biaya Bahan Bakar Boiler

Berdasarkan data tersebut, terlihat bahwa biaya untuk bahan bakar cangkang kelapa sawit lebih besar dibangdingkan biaya yang harus dikeluarkan untuk bahan bakar batu bara pada semua variasi kapasitas boiler. Hal tersebut dipengaruhi oleh jumlah pemakaian per satuan waktu ( $\mathrm{kg} / \mathrm{jam})$ dari masing-masing jenis bahan bakar. Meskipun untuk harga dasar per kilogram dari cangkang kelapa sawit lebih murah bila dibandingkan dengan batu bara, yaitu sebesar Rp. 850,- per kilogram dan batu bara sebesar Rp. 1050,- per kilogram, akan tetapi jumlah kebutuhan $\mathrm{kg} / \mathrm{jam}$ tiap jenis bahan bakar menjadi faktor yang lebih mempengaruhi besarnya biaya yang harus dikeluarkan. Pada kapasitas 2,5 ton/jam, 3 ton/jam, dan 4 ton/jam secara berturut-turut jumlah biaya bahan bakar batu bara yang dibutuhkan sebesar Rp 350.000,-/jam, Rp 419.000,-/jam, Rp 555.500,-/jam. Kemudian untuk bahan bakar cangkang kelapa sawit secara berturut-turut pada kapasitas 2,5 ton/jam, 3 ton/jam, dan 4 ton/jam jumlah biaya bahan bakar yang dibutuhkan sebesar Rp 365.500,/jam, Rp 435.500,-/jam, Rp 579.000,-/jam.

\section{Analisis Selisih Biaya Dalam 1 Bulan}

Dari data pada diagram biaya bahan bakar, dapat dilakukan analisa selisih biaya bahan bakar selama 1 bulan. Dengan asumsi dalam 1 bulan adalah 30 hari kerja dan dalam 1 hari boiler beroperasi selama 24 jam, maka 
selisih biaya bahan bakar dapat dilihat pada Tabel 1 berikut ini.

Tabel 1. Selisih Biaya Bahan Bakar Dalam 1 Bulan

\begin{tabular}{lllll} 
No & $\begin{array}{l}\text { Variasi } \\
\text { Kapasitas }\end{array}$ & $\begin{array}{l}\text { Biaya Batu } \\
\text { Bara / jam } \\
\text { (Rp) }\end{array}$ & $\begin{array}{l}\text { Biaya } \\
\text { Cangkang } \\
\text { Sawit } \\
\text { jam (Rp) }\end{array}$ & $\begin{array}{l}\text { Selisih } \\
\text { (Rp) }\end{array}$ \\
\hline 1 & 2,5 ton/jam & $350,000,-$ & $365,500,-$ & $15,500,-$ \\
2 & 3 ton/jam & $419,000,-$ & $435,500,-$ & $16,500,-$ \\
3 & 4 ton/jam & $555,500,-$ & $579,000,-$ & $23,500,-$ \\
\hline
\end{tabular}

Berdasarkan data Tabel 1 tersebut didapat rata-rata selisih Rp.18.500,- maka biaya yang harus dikelurakan dalam 1 bulan untuk bahan bakar cangkang kelapa sawit lebih besar sejumlah Rp 13.320.000,- dibandingkan apabila menggunakan batu bara.

\section{Analisis Biaya Per 1 Ton Kapsitas}

Untuk mengetahui kondisi optimal pemakaian bahan bakar, maka dilakukan analisa biaya per 1 ton setiap kapasitas boiler. Perhitungan berdasarkan data bahan bakar batu bara sebagai sampel analisa. Hasil perhitungan per 1 ton kapasitas dapat dilihat pada Tabel 2 dan Gambar 9 berikut ini.

Tabel 2. Biaya Bahan Bakar Batu Bara Per 1 Ton Kapasitas

\begin{tabular}{ccccc}
\hline No & $\begin{array}{c}\text { Variasi } \\
\text { Kapasitas }\end{array}$ & $\begin{array}{c}\text { Biaya Batu } \\
\text { Bara / jam } \\
(\mathrm{Rp})\end{array}$ & $\begin{array}{c}\text { Biaya } \\
\text { Cangkang } \\
\text { Sawit } / \\
\text { jam (Rp) }\end{array}$ & $\begin{array}{c}\text { Selisih } \\
\text { (Rp) }\end{array}$ \\
\hline 1 & 2,5 ton/jam & $350,000,-$ & $365,500,-$ & $15,500,-$ \\
2 & 3 ton/jam & $419,000,-$ & $435,500,-$ & $16,500,-$ \\
3 & 4 ton/jam & $555,500,-$ & $579,000,-$ & $23,500,-$ \\
\hline
\end{tabular}

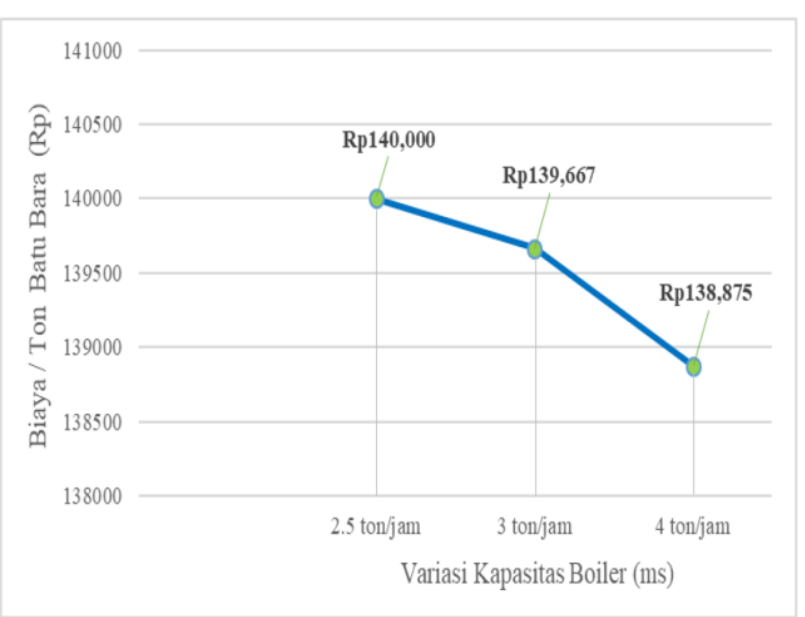

Gambar 9. Grafik Biaya Bahan Bakar Per 1 Ton Kapasitas

Berdasarkan data tersebut terlihat bahawa terdapat penurunan biaya bahan bakar per 1 ton kapasitas boiler. Untuk kapasitas boiler 2,5 ton/jam, 3 ton/jam, dan 4 ton/jam secara berturut-turut jumlah biaya bahan bakar batu bara per 1 ton kapasitas dibutuhkan sebesar Rp140.000,-/jam, Rp139.667,-/jam, Rp138.875,-/jam.
Semakin besar kapasitas beban kerja boiler maka semakin rendah biaya bahan bakar yang harus dikeluarkan untuk setiap ton. Penurunan biaya untuk setiap ton tersebut menunjukkan bahwa dari tiga variasi kapasitas 2,5 ton/jam, 3 ton/jam, dan 4 ton/jam, operasional boiler yang paling optimal adalah pada kapasitas yang paling besar, yaitu 4 ton/jam.

\section{KESIMPULAN}

Berdasarkan hasil perhitungan dan analisa yang telah dilakukan, maka pada penelitian dengan judul "Analisa Teknis Dan Biaya Penggunaan Bahan Bakar Cangkang Kelapa Sawit Dan Batu Bara Pada Boiler DZL4 Di PT. Lautan Luas Tbk" dapat diambil kesimpulan bahwa secara teknis jumlah kebutuhan bahan bakar batu bara jenis bituminous dalam $\mathrm{kg} / \mathrm{jam}$ lebih sedikit dan secara ekonomis biaya yang harus dikeluarkan untuk bahan bakar cangkang kelapa sawit lebih mahal, dengan penjelasan sebagai berikut :

1. Besar kapasitas boiler atau steam flow rate mempengaruhi jumlah kebutuhan kalor boiler. Pada kapasitas 2,5 ton/jam jumlah kalor yg dibutuhkan sebesar 1.482.476 kkal/jam. Kemudian pada kapasitas 3 ton/jam jumlah kalor yg dibutuhkan sebesar $1.778 .972 \mathrm{kkal} / \mathrm{jam}$ dan tertinggi kebutuhan kalor boiler pada kapasitas 4 ton/jam yaitu sebesar $2.371 .962 \mathrm{kkal} / \mathrm{jam}$. Hal ini menunjukkan bahwa semakin besar kapsitas yang ingin dihasilkan, maka semakin tinggi pula kebutuhan kalor dari boiler.

2. Pada kondisi moisture content yang sama ( $\pm 12 \%)$, nilai LHV setiap bahan bakar berbeda-beda, untuk batu bara jenis bituminous nilai LHV sebesar 6198 $\mathrm{kkal} / \mathrm{kg}$ dan cangkang kelapa sawit sebesar 4414 $\mathrm{kkal} / \mathrm{kg}$. Jumlah kalor yang dibutuhkan boiler dan nilai LHV tersebut mempengaruhi jumlah kuantitas penggunaan bahan bakar. Pada variasi kapasitas 2,5 ton/jam, 3 ton/jam, dan 4 ton/jam secara berturut-turut jumlah bahan bakar batu bara jenis bituminous yang dibutuhkan sebesar 304 kg/jam, 364 kg/jam, dan 483 $\mathrm{kg} / \mathrm{jam}$. Kemudian untuk bahan bakar cangkang kelapa sawit jumlah bahan bakar yang dibutuhkan secara berturut-turut pada kapasitas 2,5 ton/jam, 3 ton/jam, dan 4 ton/jam sebesar $430 \mathrm{~kg} / \mathrm{jam}, 511$ $\mathrm{kg} / \mathrm{jam}$, dan $681 \mathrm{~kg} / \mathrm{jam}$.

3. Biaya bahan bakar cangkang kelapa sawit lebih mahal dibandingkan biaya yang harus dikeluarkan untuk bahan bakar batu bara pada semua variasi kapasitas boiler. Pada kapasitas 2,5 ton/jam, 3 ton/jam, dan 4 ton/jam secara berturut-turut jumlah biaya bahan bakar batu bara yang dibutuhkan sebesar Rp 350.000,/jam, Rp 419.000,-/jam, Rp 555.500,-/jam. Bahan bakar cangkang kelapa sawit berturut-turut pada kapasitas 2,5 ton/jam, 3 ton/jam, dan 4 ton/jam biaya yang dibutuhkan sebesar Rp 365.500,-/jam, Rp435.500,-/jam, Rp579.000,-/jam. Kemudian untuk perhitungan biaya dalam rentang waktu 1 bulan (asumsi 30 hari kerja) terdapat selisih biaya yang harus dikelurakan untuk bahan bakar cangkang kelapa sawit lebih besar sejumlah Rp 13.320.000,dibandingkan apabila menggunakan batu bara. 


\section{UCAPAN TERIMA KASIH}

Penelitian ini dapat diselesaikan dengan bantuan dari berbagai pihak. Oleh karena itu ucapan terima kasih sebesar-besarnya disampaikan kepada PT Lautan Luas Tbk. dan Institut Teknologi Indonesia yang telah banyak membantu dalam usaha memperoleh data dan referensi ilmu pengetahuan, serta seluruh pihak yang tidak dapat penulis sebutkan satu persatu.

\section{REFERENSI}

[1] Akhdiyatul, Radwitya Erick, \& Chandra Yudi, Analisis teknis dan ekonomis dalam penggunaan bahan bakar biomassa di pusat listrik tenaga uap studi kasus di pltu pt.suka jaya makmur, Jurnal ELKHA, vol. 10, No.2, 2018, pp.49-55.

[2] Hasibuan Harry Christian, \& Napitupulu Farel H, Analisa pemakaian bahan bakar dengan melakukan pengujian nilai kalor terhadap perfomansi ketel uap tipe pipa air dengan kapasitas uap 60 ton/jam, Jurnal E-Dinamis, vol. 4, No.4, 2013.

[3] Yohana Elfita, Askhabulyamin, Perhitungan efisiensi dan konversi dari bahan bakar solar ke gas pada boiler ebara hkl 1800 ka, Jurnal ROTASI, vol. 14, No. 2, 2012, pp.7-10.

[4] Syukran, Suryadi Dedi, Estimasi penghematan biaya operasi pltu dengan cara penggantian bahan bakar, Jurnal Teknik Mesin, Fakultas Teknologi Industri, Universitas Kristen Petra, vol. 9, No. 2, 2007, pp: 59-66.

[5] MJ Djokosetyardjo, Ketel uap (ed. 5), Pradnya Paramita, 2003.

[6] Cengel Yunus A. \& Boles Michael A, Thermodynamics and enggineering approach ( $3^{\text {rd }}$ ed.), Mcgraw-Hill Inc, 1998

[7] Muin A. Syamsir, Pesawat konversi energi, CV.Rajawali, 1998.

[8] Arning JP, Peter W, Rieger B, \& Gose S, Pocket formula guide combustion engineering ( $8^{\text {th }}$ ed.), SAACKE $\mathrm{GmbH}$ Germany, 2016. 